Fernanda Montenegro em O mambembe:

o quelque chose da diva moderna

Fernanda Montenegro in O mambembe: the quelque chose of the modern diva

\title{
Gustavo Guenzburger
}

Gustavo Guenzburger

Doutor pelo PPGL da UERJ

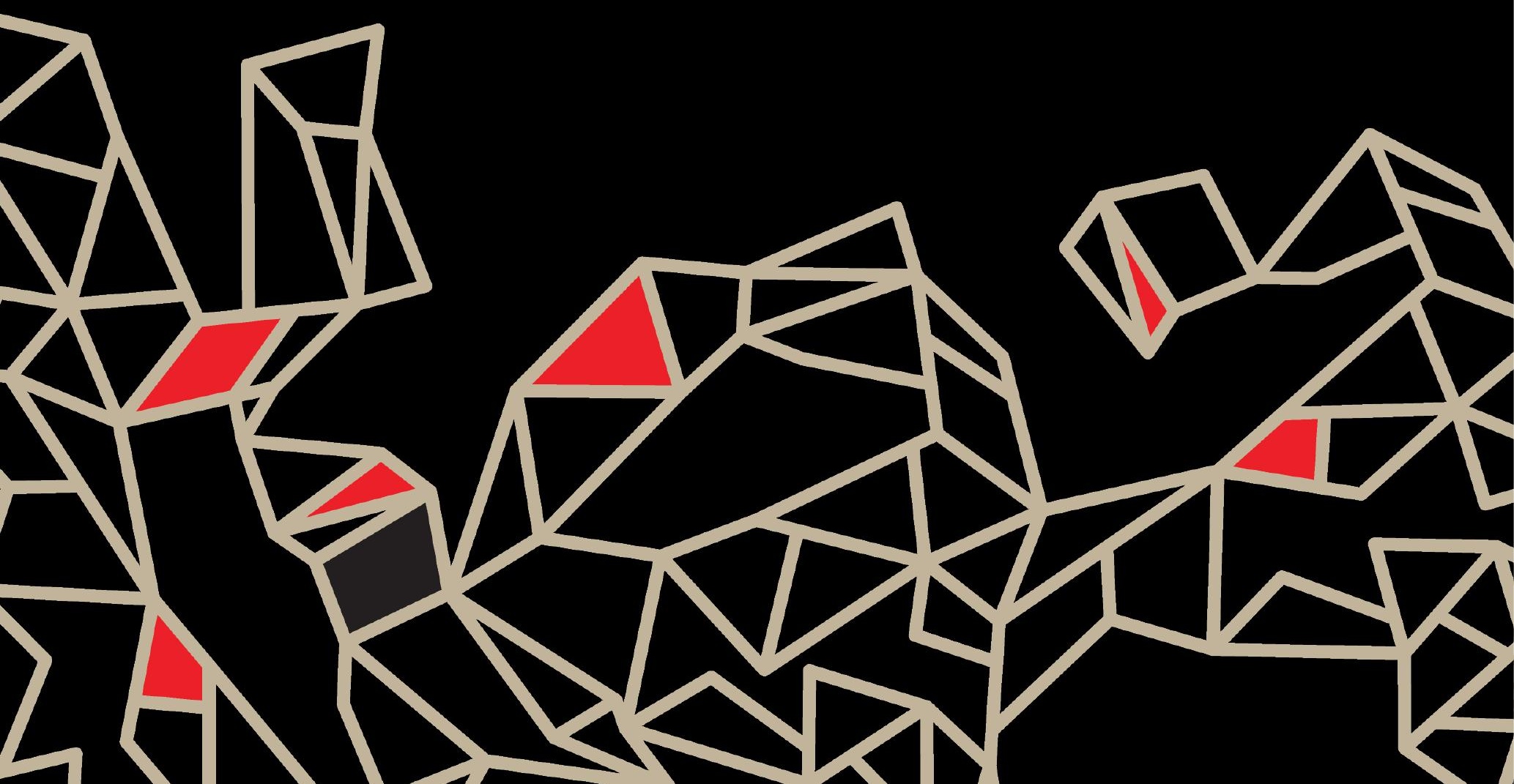




\section{Resumo}

Este trabalho é um estudo sobre a atuação de Fernanda Montenegro no papel de Laudelina na famosa montagem de $O$ mambembe de 1959, a partir de fotos, testemunhos, críticas e, principalmente, do áudio completo do espetáculo. A discussão sobre a versatilidade da atriz naquele papel pretende se conectar a uma reflexão sobre aspectos determinantes na história da atuação carioca como um todo. No momento da invenção da simbiose entre o teatro e a televisão no Rio de Janeiro, um novo e moderno "divismo" é apontado aqui como resultado de uma versatilidade artística que permitiu, a toda uma geração, negociar seu papel na interseção entre o teatro e a indústria cultural.

Palavras-chave: Fernanda Montenegro, teatro moderno, televisão, Teatro dos Sete.

\section{Abstract}

This paper is a study on Fernanda Montenegro's performance in the role of Laudelina, at the famous production O mambembe (1959), based on photos, testimonials, reviews, and especially the full audio of the show. The discussion on the versatility of the actress in that role leads to a reflection on key aspects of acting history in Rio de Janeiro. At the time of the invention of the symbiosis between theater and television in Rio, a new and modern "diva system" is pointed out here as a result of an artistic versatility that allowed a whole generation to negotiate their role in the intersection between theater and the cultural industry.

Keywords: Fernanda Montenegro, modern theatre, television, Teatro dos Sete.

Quando se pensa em uma artista bem sucedida no teatro brasileiro, o primeiro nome que vem à mente é o de Fernanda Montenegro. Grande dama e referência de qualidade, equilibra, justamente por não separar, o sustento e a criação, valor artístico e valor de mercado, amor à arte e tino profissional.

Procurei manter, neste estudo que marca uma etapa de minha pesquisa de doutorado", esse aspecto de duplicidade da carreira de nossa "atriz-sím-

1. O tema surgiu de uma instigação da professora Ângela Reis em sua disciplina na pós-graduação em Artes Cênicas da Universidade Federal do Estado do Rio de Janeiro (Unirio) sobre a história do ator brasileiro. 
bolo", ao focalizar sua atuação como Laudelina Gaioso em O mambembe, de Artur Azevedo, na montagem memorável de 1959, a partir do áudio completo do espetáculo, cedido pela própria atriz quando precisei fazer a pesquisa musical para a montagem desta peça, da qual fui também produtor e ator, por meu grupo, em 2010².

O espetáculo de 1959 inaugurou no Brasil, junto com o grupo Teatro dos Sete, uma nova forma de relacionamento entre cultura de massa e arte. Esse é um problema com o qual, de certa maneira, Artur Azevedo já se via às voltas (MENCARELLI, 1999), tendo de escolher entre o sustento pela indústria de musicais e o "bom teatro", o qual, no entanto, era incapaz de se sustentar. Entrelaçado à atuação de Fernanda aparece aqui este problema extrapalco, que o enredo da peça já abordava parcialmente em 1904, e para o qual a geração do Teatro dos Sete forjou soluções que em parte perduram até hoje.

Se $O$ mambembe de Artur Azevedo não obteve em 1904 o mesmo êxito que obteria com o Teatro dos Sete 55 anos depois, muitas são as razões, e estão ligadas à forma como o público de cada época se ligou ao material cênico apresentado por cada montagem. Se, na virada para o século xx, Azevedo esteve assustado com o rumo industrial e massificado do ramo musical ligeiro, no qual ele tanto se destacara, pode ter pensado $O$ mambembe como um libelo às origens do teatro (GUENZBURGER, 2011a, 2011b), em uma tentativa de acomodar a esse mercado de musicais um tipo mais conservador e elitizado de comédia de costumes, que ele considerava mais "artística". Com esta e outras peças, em críticas ou em seu festival de comédias de costumes na Exposição Nacional de 1908, Artur podia estar finalmente tomando partido, no final da vida, numa questão em que durante o século XIX mantivera um comportamento ambíguo: a da disputa entre arte e entretenimento.

A partir da época de $O$ mambembe, Artur Azevedo admite como única salvação para o teatro "sério" brasileiro a construção do Teatro Municipal, ou seja, para haver um teatro profissional verdadeiramente artístico, o governo deveria sustentá-lo. Isso nunca aconteceu totalmente, e a questão ainda está em pauta no século XXI.

2. Ver O Globo (2010). 
Mas, em 1959, tudo levava a crer que o teatro moderno brasileiro seria capaz de criar para si um mercado autossustentável ${ }^{3}$, mesmo sem a ajuda do governo. Nisso acreditavam os entusiasmados criadores do Teatro dos Sete e toda sua geração. Fariam de tudo para levar adiante seu projeto, de espetáculos que fossem ao mesmo tempo nacionais e modernos. A estreia aconteceria na casa sonhada por Artur Azevedo, o Teatro Municipal do Rio de Janeiro. Diante da inexistência de patrocínios ou de um público certo, a solução financeira imediata que encontraram para essa ousada empreitada foi, talvez, a primeira campanha documentada de divulgação de teatro pela televisão brasileira, que aconteceu quase espontaneamente, quando Sérgio Britto, então diretor e apresentador do Grande Teatro, na TV Tupi, resolveu dizer ao final de um programa: "Há três anos vocês assistem ao nosso programa, e pela audiência vocês mostraram que acreditam em nós de verdade. O que eu quero de vocês é o seguinte: façam uma assinatura da nossa temporada" (BRANDÃO, 1992, p. 68).

Na versão de Gianni Ratto, diretor do Teatro dos Sete, essa relação pode não ter se dado tão por acaso assim, ou pelo menos ter se dado a partir de uma consciência mercadológica por parte dos componentes do grupo: "Então se formou a ideia de fazer um espetáculo. Porque o Sérgio [Britto] tinha muita penetração, tanto o Sérgio quanto a Fernanda, por causa da televisão. [...] Antes de começar, tínhamos um público já pronto para ir ver a gente" (BRANDÃO, 2005, p. 166).

De repente, a TV começa a ser critério para a produção de uma peça. $\mathrm{Na}$ época de escolher o elenco, Fernanda teria dito:

Sérgio, você e eu temos feito par romântico de quase a metade do repertório do Grande Teatro Tupi, o público nos espera como par romântico e não pode ser decepcionado. Você vai fazer meu galã, papel meio bobo, mas que precisa ser feito por você. (BRITTO, 1996, p. 107)

Dessa maneira, a televisão também ajudou a escolher o elenco de 0 mambembe, entrando definitivamente no palco brasileiro. Desenvolvida de-

3. Moderno aqui já pressupunha um caráter "artístico", em contraste com o teatro convencional, que na época se considerava como atrasado, indisciplinado e voltado apenas para a bilheteria. 
pois em escalas que na época eram inimagináveis, de lá para cá esta mistura moldou, financiou, divulgou, prestigiou e consagrou teatro e televisão reciprocamente, tornando difícil, em alguns contextos, falar de uma coisa sem relacioná-la à outra, principalmente no Rio de Janeiro ${ }^{4}$.

Esse processo de amalgamento criou, para as bilheterias do teatro carioca, uma dependência crescente do destaque de nomes televisivos nos elencos. Mais recentemente, o teatro com pretensões artísticas passou a depender do dinheiro governamental, porque, após algumas décadas de desenvolvimento dentro do sistema de estrelato, novamente voltou a não dispor de público suficiente para sustentá-lo - muitas vezes concorrendo com a própria televisão que antes ajudara a projetar ou criar suas estrelas. A multiplicação contemporânea das formas de fomento estatal tenta acompanhar e sustentar a explosão de novas linguagens cênicas na cidade, mas é incapaz de garantir a lógica de longo prazo do sustento de seus artistas. Hoje, quase sempre um ator ou atriz iniciante no Rio de Janeiro só concretiza sua profissionalização na TV, ou - como na era pré-TBC (Teatro Brasileiro de Comédia) - no teatro industrial dos grandes musicais e do humor ligeiro. Ao mesmo tempo, o mercado de televisão vai se libertando da necessidade de arregimentar no teatro suas figuras principais, como fez a partir da geração do Teatro dos Sete.

Fernanda Montenegro perpassa cada uma dessas etapas do teatro e da televisão brasileiros, surgindo como que em uma encruzilhada de gerações. Apesar de começar a carreira no final da década de 1940, nunca participou dos novos grupos amadores da época, onde se forjava o novo teatro. Segundo seu próprio testemunho, sua universidade foi "o trabalho na Rádio MEC", sua pós-graduação foi "o teatro ao vivo na TV Tupi” (COELHO, 1982, p. 32-45), e sua trajetória profissional no palco começa junto à geração de artistas anterior à sua, que ainda usava o ponto, e que estreava uma peça sem conhecer o texto inteiro, mas apenas suas próprias falas e as "deixas" dos colegas. Depois aprendeu a disciplina e a profundidade da tradição francesa com a companhia de Henriette Morineau; em seguida, as práticas modernas do teatro com Gianni Ratto na Companhia Maria Della Costa - onde recebeu seu primeiro texto inteiro para ensaiar; logo após, entrou para o TBC, que lar-

4. Apesar de trabalhos acadêmicos muitas vezes fazerem certa vista grossa para este fato evidente no teatro carioca recente. 
gou ao se fixar no Rio de Janeiro, para trabalhar no Grande Teatro da TV Tupi e fundar o Teatro dos Sete, com Ítalo Rossi, Sérgio Britto, Fernando Torres e Gianni Ratto (COELHO, 1982; MONTENEGRO, 1988; RITO, 1990)

Sem perder de vista Fernanda Montenegro como símbolo de uma geração de artistas que conseguiu até certo ponto subverter a lógica que impedia o teatro de se desenvolver na direção de uma arte autossustentável, vamos comentar aqui sua atuação em O mambembe, a partir de críticas, fotos, depoimentos e principalmente do áudio do espetáculo 5 . As balizas e critérios para a análise de uma performance de 55 anos atrás, além de muita imaginação, serão: a formação prévia da atriz; a ideologia do espetáculo, de se misturar atores modernos e antigos para reinventar uma época teatral esquecida - ou ignorada e portanto fantasiada, como tenho afirmado em trabalhos anteriores (GUENZBURGER, 2011a, 2011b); os estilos e escolas de interpretação que se intercalam - realista, melodramático, comédia ligeira, farsesco, etc.; e finalmente as interessantes coincidências entre atriz e personagem: Laudelina vive a tentativa e a impossibilidade de viver de sua arte, de levar seu talento do palco amador para o mundo profissional, enquanto Fernanda faz parte de uma geração que fundou novas formas de fazer isso. (E O mambembe de 1959 é um marco divisório neste sentido, um teatro que pôde se dar ao luxo até mesmo de ser antigo e refinado, pois seus principais atores já eram comprovadamente modernos na TV, além de, é claro, serem sustentados por ela.)

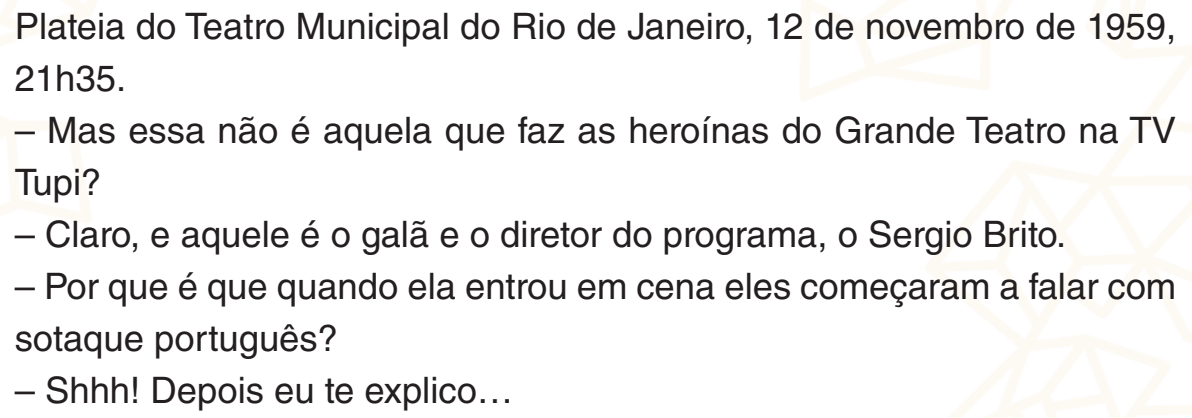

A peça é a burleta de 1904, O mambembe, de Artur Azevedo e José Piza, e a mocinha é Laudelina Gaioso, interpretada por Fernanda Montene-

5. Do espetáculo quase completo: três fitas K7 (digitalizadas pelo pesquisador) do arquivo pessoal de Fernanda Montenegro. Essas gravações foram feitas e guardadas durante cinquenta anos por Alfredo Souto de Almeida.

6. Incluindo diálogos fictícios a partir de depoimentos, críticas e reportagens de jornais. 
gro, que ao entrar em cena encontra seu pretendente, Seu Eduardo (Sergio Britto), ajoelhado, aos pés de Dona Rita, tia e mãe de criação da moça. O cotidiano do Seu Eduardo é o de um pequeno funcionário público bem-comportado, mas no Grêmio Recreativo Teatral do Catumbi ele interpreta os mais arrebatados heróis, verve romântica que deixa escapulir para sua vida real, quando se trata da paixão que sente por sua companheira de palco amador, Dona Laudelina. Na primeira cena da peça, Seu Eduardo acorda cedo para visitar a amada, após ambos terem representado na noite anterior A Morgadinha do Val Flor. Depois de receber de Dona Rita o apoio a suas intenções para com a mocinha, o mancebo, em mais um arroubo de amante apaixonadíssimo, se ajoelha aos pés da tia da jovem, agradecendo como se estivesse em um drama romântico.

Laudelina entra em cena exatamente neste momento, e não se faz de rogada: através de um grito agudo, volta à personagem da noite anterior e aproveita o clima apaixonado para começar a representar novamente o dramalhão:

“- Ah! Um discípulo de Voltaire, ajoelhado aos pés da cruz..."7

Seu Eduardo imediatamente entende o jogo:

"-A cruz é o amparo dos que padecem!"

Ao tomar a forma metateatral de um ensaio improvisado na sala de estar, a cena, que até então era representada em um coloquial elegante, de época, toma ares de um teatro mais ingênuo e antigo, com gesticulação arrebatada, vozes empostadas, frases cantadas na tradição da oratória lusa e o famoso sotaque português. Supõe-se que esse sotaque seria o mais usado pela tradição amadora do teatro dos subúrbios cariocas de início do século, então dominados pela cultura e pela população emigrada de Portugal durante todo o século XIX. Tudo isso o Teatro dos Sete executa com precisão e consciência em 1959.

Pelo menos é o que podemos pressupor ao ouvirmos o áudio completo da peça ao vivo. Impressionam a agilidade, a disponibilidade e a compreensão de linguagem daquela atriz que faz a jovem amadora interpretando a mocinha romântica. Como poderia Fernanda Montenegro, uma atriz ainda razoavelmente jovem, 30 anos na época, que fez boa parte de sua formação

7. As falas da peça não estão acompanhadas da indicação de citação autor-data por terem sido todas elas retiradas da gravação de áudio do espetáculo (fonte citada acima). 
na TV e rádio, ter tamanho domínio sobre um estilo tão distante quanto difícil de se executar naquelas condições? Para tentar responder a essas e outras perguntas sem, no entanto, reduzir nossa análise apenas ao áudio da peça, ou à imaginação da cena e da plateia, consultaremos alguma bibliografia sobre a atriz.

Ler os depoimentos biográficos de Fernanda com o pensamento em $O$ mambembe põe à mostra similitudes e diferenças entre personagem e intérprete, quanto aos problemas colocados em relação à formação e à profissionalização do artista e suas soluções, seja no enredo da peça seja na trajetória da atriz.

Laudelina e Fernanda foram criadas no subúrbio do Rio de Janeiro, em famílias de classe média baixa. Se Laudelina Gaioso se descobriu e se formou atriz nos dramalhões do Grêmio Recreativo Teatral do Catumbi, Arlette Pinheiro Esteves - nome de batismo de Fernanda - estreou no drama Os dois sargentos, no grupo teatral da paróquia São Sebastião, no bairro de Jacarepaguá ainda rural dos anos 1930. Ambas deparam cedo com a difícil realidade de penúria do teatro brasileiro e com a falta de mercado para sua arte. Ambas têm o temperamento necessário para enfrentar esse obstáculo, colocando-se em movimento, criando novos espaços, novas plateias; uma "mambembando", e a outra, negociando sua arte na lógica da cultura de massa. Para as duas, a chama do teatro deve continuar acesa, mesmo que para isso tenham de barganhar com elementos extra-artísticos, como veremos adiante.

Fernanda iniciou a profissão na rádio Ministério da Educação, onde, além de trabalhar como redatora e radiatriz, teve uma primeira formação com profissionais basicamente lusitanos: "aulas de português com Otacílio Rainho, de declamação com Martinho Severo, de avaliação dramática de texto com Esther Leão" (RITO, 1990, p. 27).

Portanto, não era a primeira vez que ela enfrentava o estilo romanesco e o sotaque português. E na "cena dentro da cena" do começo de O mambembe, percebe-se a desenvoltura do trio Fernanda-Sergio-Ítalo frente a essa brincadeira teatral. No caso de Fernanda, aparece inclusive o cacoete radiofônico para o estilo melodramático, com inúmeras interjeições do tipo "oh!", “ahhnn...," "ah!", que marcam as reações da personagem auditivamente, o que para nós, que acompanhamos a apresentação através da gravação de áudio, 
é muito bom. Mas provavelmente para a plateia que via o corpo dos atores em 1959 aquilo era uma redundância, desculpada no início de espetáculo por causa da estilização da "peça dentro da peça". Depois, quando um pouco do estilo declamatório "vaza" para as outras cenas do espetáculo, a plateia já se acostumou e aceita de bom grado os barulhinhos de Fernanda, o português castiço, levemente luso, e o tom didático de todo o elenco, assimilando tudo como um jeito antigo e ingênuo de ser. Hoje, podemos pensar em como a formação de radialista de Fernanda pode ter contribuído para esse encontro estilístico feliz, entre dicção afetada, sotaque português e certa relação didática para com a interpretação, no sentido de desenvolver uma personagem dentro de determinado estilo e ao mesmo tempo ensinar seus códigos para a plateia, que os desconhece ou os esqueceu.

A entrada de Frazão em cena é um momento de inteligência de Fernanda. Laudelina, que até então vinha, como os outros, colocando todo o seu sentimento nos versos derramados da "Morgadinha de Val-flor", quando percebe a presença do grande ator em sua casa, não consegue parar de representar o drama, com a mesma melodia e sotaque afetados, mas agora sem energia, no agudo, como se a voz lhe fosse falhar - e aqui imaginamos aqueles olhos expressivos de Fernanda se esbugalhando -, apalermada ou enfeitiçada com a presença do grande ídolo. Um pequeno momento que a plateia entende e acompanha com uma risada geral.

Depois da saída desconfiada do jovem e amador galã do Catumbi, Frazão propõe contratar Laudelina para primeira dama de sua companhia mambembe. Faz essa proposta à tia, madrinha e mãe adotiva da menina, como mandava o recato da época. Dona Rita nega imediatamente, dizendo que a menina não se destina ao teatro e que se assim o fosse, não o seria em um mambembe. Frazão retruca que o mambembe é o meio ideal para se começar uma carreira, pela possibilidade de experimentação em vários papéis diante de um público menos exigente que o da capital. Neste momento, começam a aparecer as principais características que Laudelina exige de Fernanda: versatilidade, maleabilidade e capacidade de se adaptar rapidamente a novas situações. Dona de temperamento forte, Laudelina está sempre disposta a tudo para conseguir o que quer, e nesta cena usa todas as estratégias a seu alcance - e ao alcance da intérprete - para convencer 
a tia de que ela deve aceitar o convite do ator/empresário. Fernanda começa por um tom choroso e de lamento em uma melodia triste e sóbria, mas bem à francesa - com a última sílaba tônica da frase marcada por um agudo, tal como ela deve ter aprendido nos anos em que atuou na Cia de Henriette Morineau: "que futuro me espera fora do teátro? Ser costureira a vida tôda? Casar-me com Seu Eduardo que não ganha o suficiente para viver soltêiro? Encher-me de filhos e de cuidádos?" De repente, a menina suburbana, direta e realista, solta o argumento: "se tenho, como dizem, algum jeito para o teatro, não seria melhor aproveitar a minha habilidade?" Depois a personagem passa para o tom de conluio, quando tenta tramar em segredo com Frazão a sua ida, para finalmente extravasar todo seu temperamento, dizendo que se a tia não deixar, ela irá mesmo assim, com ela ou sem ela. Para cada uma destas Laudelinas, uma Fernanda, que se sucede à outra em uma velocidade incrível. Elas nunca se confundem, variando de tons, estilos e mesmo de registros de estratos sociais, pois Laudelina/Fernanda está na encruzilhada de todos eles.

Na mesma noite - corredores do Teatro Municipal, intervalo do primeiro ato. ${ }^{8}$ [Fernando Sabino] - Mas olhe que eu sou empedernido para teatro, quase não vou, e convenhamos... o texto do Artur Azevedo não me animou muito... Mas essa noite parece que o teatro está encantado, nunca vi nada tão lindo e contagiante. ${ }^{9}$

[Cândido Portinari] - Pois eu fui o primeiro a fazer minha assinatura para a temporada, liguei assim que vi aquele rapaz anunciando a peça na TV. Aliás, eu não perco um Grande Teatro. O engraçado é que quando vieram me entregar os bilhetes da assinatura o entregador era ele mesmo, o próprio diretor e apresentador do Grande Teatro. ${ }^{10}$

[Sabino] - O Sergio Britto? Com certeza deve ter feito questão de ir the entregar, deve ser um grande fã do seu trabalho.

[Portinari] - Pois eu é que sou fã desses jovens do Grande Teatro. E quem não é? Eles estão tirando um atraso enorme do Rio de Janeiro em relação ao repertório universal. Toda semana é uma peça ou romance novo, e com que classe! $E$ hoje... eles merecem esse sucesso. Você

8. Diálogo fictício, imaginado a partir de informações contidas em depoimentos e notícias da época.

9. Ver Sabino (1959, p. 7).

10. Ver Brandão (2002, p. 311). 
viu como cada mudança de telão do cenário era aplaudida? E olhe que eram aquarelas, tão simples quanto funcionais e belas. Eu tinha falado que esse diretor italiano não era bobo, cansou de fazer cenário para o Giorgio Strehler na Itália...

[Pascoal Carlos Magno] - Alguém tinha que dar uma medalha pra esse italiano, a Ordem do Cruzeiro do Sul! (MAGNO, 1959, p. 3)

[Portinari] - E a aquela música da menina que quer ser atriz? Na segunda repetição já tinha gente da plateia cantando com ela "Elle a quelque chose là"...

[Sabino] - Quase não deixaram a peça continuar de tanto que aplaudiram a moça depois da música. Mas também, que graça, que leveza...

Bárbara Heliodora, para começar sua crítica sobre o espetáculo desta mesma noite, disse que

[...] ao fim do primeiro ato os encontros de amigos nos corredores do Teatro Municipal eram mais efusivos do que de costume: o clima de alegria, de amor que se criara no palco era absolutamente contagiante, provocando esta perfeita integração de espetáculo e plateia que é o verdadeiro fenômeno dramático. (HELIODORA, 1959, p. 6)

Quanto à graça e leveza que Fernando Sabino achou na Laudelina de Fernanda Montenegro, estes adjetivos aparecem em diversos elogios de outras reportagens e críticas da época (SALGADO, 1959, 1960). Mas leveza e graça são termos pouco técnicos e bastante subjetivos, e hoje, ao analisar o áudio recuperado da peça, nos esforçamos para procurar o que está por trás da impressão que Fernanda causou na plateia e na crítica. Ou seja, ser graciosa e leve em um papel de difícil execução, devido às mudanças bruscas de humor, intenção, intensidade e estilo, que de uma hora para a outra a personagem exige da intérprete.

Em 1904 o gênero leve era o lugar comum entre os atores da indústria de musicais da capital federal. Mas ser leve em 1959, para uma atriz de temperamento dramático, como estava se firmando a imagem de Fernanda Montenegro, não era algo tão provável. E por isso, o resultado da atriz neste papel ajudou a confirmá-la como "atriz completa" na "privilegiadíssima posição que ocupa no teatro nacional" (HELIODORA, 1959, p. 6), conferindo novas possibilidades àquela jovem intérprete. 
Para tentar examinar estas características, no palco de 1959 que ouvimos e imaginamos, vamos analisar o incrível desempenho de Fernanda na sequência principal de Laudelina, em que esta tem participação central na peça, ao tomar para si a responsabilidade de salvar o mambembe que está encalhado na cidade perdida de Tocos, sem dinheiro para ficar ou sair. O trecho começa quando o casal Laudelina e Seu Eduardo encontra aquele que pode tirá-los da enrascada: o Coronel Pantaleão Praxedes Gomes, obtuso senhor feudal e autor do drama em doze atos A passagem do mar amarelo, descendente direto dos vecchios lúbricos da commedia dell'arte, e provocação de Artur Azevedo a certo autor amador, seu contemporâneo"1. Com o consentimento do coronel, Seu Eduardo sai de cena para levar as malas da companhia ao teatro da cidade, dando ingenuamente um conselho para sua amada, do qual mais tarde iria se arrepender: "Trate de agradar-Ihe", e Laudelina pergunta: "Agradar-Ihe? Mas como?" Este é o mote da sequência que vai terminar sem resolução, na cena em que Laudelina está frente à delicada tentativa de salvar o mambembe arrancando algum dinheiro do velho e babão Coronel Pantaleão, sem que para isso tenha que perder de vez sua condição de mocinha recatada.

Na primeira cena da sequência, Fernanda serve de contraponto e "escada" para Renato Consorte dar um show de histrionismo em seu caricato Pantaleão, autor amador que tenta justificar os doze atos de sua peça, onde o povo de Moisés sai da Palestina para o Egito, mas não apenas atravessando o mar vermelho, pois "seria uma coisinha a toa. Quis dar mais peripécias ao drama", e com isso arranca diversas gargalhadas da plateia. Consorte mostra um repertório imenso de truques e técnicas farsescas de interpretação, como quando recita trechos de $A$ passagem... com todas as ênfases deslocadas para sílabas tônicas de palavras secundárias, deixando praticamente incompreensível o conteúdo da peça do Coronel, expondo a pouca experiência da personagem nos assuntos da arte dramática. Neste momento, coadjuvante em cena, Fernanda coloca sua Laudelina totalmente em função do encorajamento ao Coronel, e tudo a ajuda neste sentido, texto, movimentação - ouvimos os passos no tablado

11. O Comendador Fonseca Moreira, autor do drama A passagem do Mar Vermelho, sofreu com as ironias do cronista Artur Azevedo. Ver O Teatro. A Notícia, Rio de Janeiro, 16/01/1902 e 04/02/1904 (apud AZEVEDO, 2010). 
- e partitura - neste momento já estão cantando. Quando Laudelina, que obviamente entende a debilidade artística do velho, cinicamente sugere: "Coronel, por que razão não aprende o francês e não vai para a França?", a tessitura aguda do trecho permite à Fernanda empostar a voz de cabeça, e ela aproveita para emprestar um tom operístico, mais solene, à cena. Quando sugere outra coisa mais factível, ou seja, oferecer o tal drama à companhia Frazão, seu canto toma uma forma de canção, mais coloquial, e a melodia vai subindo à medida que Laudelina aumenta o encorajamento e a bajulação "e o povinho gritando - que belo!/ Bravos! Bravos! À cena o autor da Passagem do Mar Amarelo!"

Esta é uma possibilidade técnica a se destacar em Fernanda Montenegro aos seus trinta anos. Apesar de não possuir esta bagagem em sua carreira, a atriz demonstra uma técnica impecável e uma compreensão incrível da versatilidade expressiva que o canto pode lhe proporcionar. Aparentemente um mezzo-soprano à época, Fernanda domina as maiores dificuldades para este tipo de voz, que são as passagens e as notas intermediárias entre a emissão de peito, mais grave e comum ao cancioneiro popular, e a de cabeça, mais aguda e mais afeita ao canto lírico. E o que seria dificuldade para uma cantora - principalmente com pouca experiência - se transforma em ferramenta de interpretação, pelo talento e pelo trabalho minucioso da atriz. Ela pode ser operística em alguns poucos momentos como já vimos, ou quando enaltece o fato de o Coronel ser presidente da Câmara Municipal em agudos dignos de uma Aída. Mas a voz de cabeça, misturada com peito ou não, pode ser também suave, para um efeito choroso, ou para dar um tom afetado de música de câmara, quando a intenção é a de um canto sofisticado e estrangeiro, como quando ela capricha no legato rallentando sostenuto ${ }^{12}$ antes de entrar no verso em francês "Elle a quelque chose là." Grande parte do tempo a partitura permite que a atriz cante com sua voz de peito normal, a mesma que usamos para falar, o que torna seu canto semelhante ao da canção popular, proporcionando maior identificação com a personagem.

12. Esta não é exatamente a indicação de ritmo da partitura de 1954 feita por Antonio Manoel Lopes, o maestro Kalua, diretor musical e regente do espetáculo. Algumas (quatro) canções ele tinha conseguido recuperar de partituras originais de 1904 - as outras foram de sua própria autoria. Muitas das variações rítmicas e das dinâmicas descritas aqui devem ter surgido durante os ensaios, pois são diferentes ou não estão escritas nestas partes, que estão disponíveis na biblioteca da Fundação Nacional de Artes (FUNARTE), acervo Labanca. 
Hoje em dia, em uma época onde os musicais são basicamente divididos entre brasileiristas ou americanistas, os cantores-atores e cantrizes se dividem e se especializam entre o canto popular brasileiro e a técnica importada do belting voice americano, que é o canto nasal de pouca emissão inventado para os microfones de lapela. Em 1959, apesar de os musicals americanos já terem invadido nossas telas, eles ainda não o tinham feito em relação a nossos palcos - o que só começaria quatro décadas depois -, e muito menos invadido nossa sensibilidade musical de plateia, como ocorre hoje, quando se aceita como normal que atores cantem em português com sotaque norte-americano. Portanto, é muito interessante ouvir uma atriz da época em que teatro sério não podia ter música, uma atriz que não era cantora - e continua não sendo até hoje -, tentando jogar com as regras do cantar de seu tempo. Aproveitando tudo o que podia de todas as tradições eruditas e populares, estrangeiras e nacionais de que teve conhecimento e contato - trabalhou com grandes cantores no rádio e TV -, já que a ideia era estabelecer as bases para um teatro musical que fosse brasileiro mas $\mathrm{chic}^{13}$. Aquele projeto não aconteceu e Fernanda só voltou a cantar em cena em 1990, na peça Suburbano coração, mas deixou claro em O mambembe que o poderia fazer a qualquer tempo, com a propriedade de uma grande intérprete.

Voltando à peça...

O sexto quadro - metade do Ato II - se inicia com a notícia de que a apresentação da peça do Coronel Pantaleão foi um fiasco, e que depois disso o Coronel não quer mais nada com a companhia Frazão, que também não tem como sair de Tocos. De tudo isso ficamos sabendo em um ataque de nervos de Dona Rita para cima de sua afilhada, que só se lamenta e chora. Em uma cena digna da comédia de costumes mais rasgada, Fernanda aproveita para dar um contraponto farsesco ao histrionismo da atriz veterana Grace Moema. Grace integrava a parte do elenco contratado pelo Teatro dos Sete

13. Na introdução de minha dissertação (GUENZBURGER, 2011a, p. 12), coloco a descoberta das partituras e do áudio da peça como um dos motivadores de minha questão de pesquisa no mestrado, que levou em conta a mudança de posição de Artur Azevedo quanto à industrialização - e, para ele, a vulgarização - do teatro ligeiro na virada do século xx. A musicalidade do material de 1959 e de 1904 contrariou todas as minhas expectativas de encontrar os ritmos brasileiros que estiveram presentes nas revistas do próprio Artur Azevedo em décadas anteriores. Nas partituras de $O$ mambembe, ao invés de lundus, encontramos dobrados. Ao invés do tango brasileiro, valsas rápidas e marchas afrancesadas. 
que realmente vinha da tradição convencional e, segundo Barbara Heliodora, mostrou "o que pode render uma longa tarimba teatral nas mãos de quem saiba canalizá-la." (HELIODORA, 1959, p. 6) Nos lamentos e choros de Laudelina, Fernanda abusa daquele seu divertido agudo esganiçado que mais tarde o Brasil inteiro aprenderia a amar através da televisão via satélite. A cena cresce tanto que é a própria Tia Rita que, em determinado momento, tem de parar de repreender a sobrinha para acalmá-la, e em seguida continuar no tom anterior - uma cena de inversão típica de comédia convencionada, sem qualquer pingo de lógica psicológica, e que delicia a plateia.

Quando a tia sai, começa um pequeno monólogo - à parte - de Laudelina, à la Colombina, onde esta divide com o público a intenção de remediar a situação que ela mesma havia criado, e para tanto, só vê uma saída.

"É embelezar o Coronel Pantaleão até que ele se explique." Fernanda dá um tom suburbanamente pragmático. Mas imediatamente depois, o lado recatado da mocinha sente o terror da rejeição social, e a atriz opera uma mudança seca para a voz chorosa e angustiada:

"Mas o que é que eu vou parecer aos olhos de Seu Eduardo? Que juízo fará ele de mim?"

Nesse momento, o jovem apaixonado e desiludido entra em cena, e a Laudelina de Fernanda se vê entre estudar a situação, escolher a melhor maneira de entrar no assunto com ele e ainda pensar em um afago qualquer para acalmar o moço. Não que a cena entre em um tom intimista ou naturalista - Fernanda começa o diálogo disfarçando em uma afetação digna de uma comédia de Moliérè ou Maquiavel: "Já... tão cedo na rua?" -, mas o que aparece na cena - uma das melhores da montagem - são dois atores maduros e modernos, e no caso de Fernanda com uma capacidade bem treinada de fazer a personagem lidar com diversos pensamentos concomitantes em cena e expressá-los com clareza, por detrás das palavras do texto. Sergio Britto dá um tom sério, usando pela primeira vez o lado funcionário público do personagem, que está de mau humor, desesperado menos pelo fiasco do mambembe, e mais pela falta de uma esperança qualquer por parte de Laudelina. Ele reclama que ainda por cima é obrigado a ter ciúmes até do Coronel Pantaleão, "bem velho e casado!"

— "Mas não foi o senhor mesmo que me recomendou que agradasse 0 
coronel?

- Sim, agradasse, mas não tanto! [gargalhadas da plateia]"

Quanto mais cômica a cena, mais seriedade Fernanda empresta à sua personagem, dando um tom preocupado, principalmente no tocante à preocupação com sua honra:

— "Tanto como...?"

A essa altura Seu Eduardo volta a ser o galã incorrigível, e ao mesmo tempo que briga com a amada, aproveita a deixa para se ajoelhar e lhe beijar a mão...

— "Deixando que ele lhe pegue na mão assim... e a beije...

[Laudelina, cheia de dignidade] — Alto lá! Ele nunca me beijou a mão! [agora à la Dercy Gonçalves] Pegou nela, isso pegou..." Depois da risada da plateia, ela continua com a resignação de uma sofredora: "E me disse até umas bobagens... Mas se eu me zangasse não teríamos o que comer... Francamente, Seu Eduardo, era preciso dar-Ihe esperanças..."

[Seco] - Essas esperanças não são dignas da senhora!"

Neste momento o diretor Gianni Ratto arrisca uma grande pausa psicológica, digna de uma peça realista americana, que parece surtir efeito e que trabalha a favor da encenação no sentido de preparar um ponto de mudança na trama, uma virada nas personagens. A partir desta "respiração" da peça, Laudelina decide seu destino: aconteça o que acontecer no mambembe, ela definitivamente se casará com Seu Eduardo, e revela isso ao jovem, de maneira sentida, pela primeira vez. Afinal ela sinceramente gosta dele e, ao contrário do galã do Catumbi, é uma mulher prática. O delicioso na cena é justamente esse contraste entre os dois:

— "Ah! Repita! Diga que me ama!..."

— "[...] O verbo amar só se emprega no teatro e no romance [...] Eu gosto do senhor; vem a dar na mesma [...] e hei de ser sua mulher.' Seu Eduardo, apaixonado e feliz, é entretanto avisado de que haverá uma condição: a de só considerá-la sua noiva quando estiverem de volta ao Rio de Janeiro, pois no mambembe a vida "é toda anormal e fictícia". A carta branca do jovem para a mocinha é negociada em um dueto musical divertido, em que Seu Eduardo é praticamente obrigado a jurar que irá se comportar, mesmo que para conseguir o dinheiro do coronel, "seja isso embora muito duro", Laudelina tenha 
que "com alguém ficar no escuro...." Ataque de orquestra: "Perdão, isso eu não juro!" O mancebo só cede mesmo com o argumento final de Laudelina, "Se não jura eu Ihe asseguro", que Fernanda coloca em rallentando charmosíssimo, distraído e agudo como uma menina pura de sete anos: "não se-rei... su-a mu-lheeer..." Ele vai jurar tudo que ela quiser - e se arrepender depois.

O campo está limpo para a cena mais quiproquó da peça, quando Laudelina vai finalmente dar muitas esperanças ao coronel babão, a fim de conseguir dele o dinheiro das passagens de volta ao Rio de Janeiro. Nessa cena, Fernanda se sente livre para acelerar o processo de mudanças de estado abruptas que vem desenvolvendo aos poucos na personagem, de acordo com o que pede a trama, sem grandes preocupações com a coerência psicológica. $\mathrm{Na}$ hora do tudo ou nada, o que parece valer para a intérprete é menos uma psicologia que o embate entre os personagens, o jogo, é o teatro na sua forma mais pura e arcaica, das paixões representadas em cena. Exemplo disso são as três tentativas de aproximação iniciais, "Meu caro coronel..., primeiro sussurrado à la Marilyn Monroe em Happy Birthday, Mr. President, depois repetindo a mesma frase como uma lavadeira determinada, e depois que o coronel aceita o jogo - "Coronel, não!/ chama-me antes Leão,/diminutivo de Pantaleão!" -, finalmente ela se aproxima como uma "carneirinha" sonsa brincando na cova dos leões: "Meu caro Leãozinho, Leãozinho, Leãozinho... que meiguice, que carinho!" A cena termina sem solução, com Seu Eduardo não suportando os ciúmes e saindo do esconderijo para dar um trambolhão no velho safado.

Em sua época, lidando com o recente fenômeno industrial dos musicais, Artur Azevedo sempre creditou ao atraso nacional a situação "pouco artística" de nossa cena. Daí talvez a metáfora de $O$ mambembe se encaminhar para um antagonista arcaico, tirado da comédia italiana antiga. Artur Azevedo coloca sua Laudelina/Colombina negociando com um elemento extra-artístico, vecchio arcaico, porém também financeiro, de quem o teatro depende para seguir sua viagem. ${ }^{14}$ Já Fernanda Montenegro e sua geração, ao contrário de Azevedo, nunca encararam nem o teatro de bulevar e nem o fenômeno da comunicação de massa televisivo enquanto atraso ou enquanto futuro, mas

14. Ver Guenzburger (2011a, 2011b). 
como possibilidades diferentes de veículos para sua arte. Talvez por isso nunca tenham tido grandes dificuldades em negociar com a indústria da imagem os meios para conseguirem levar adiante os seus próprios carros de Téspis.

A montagem de $O$ Mambembe está no cerne desta virada de valores, por propor um teatro que se justifica por si próprio, seja ele moderno, engajado, brasileiro, intelectual, ou antigo, divertido, afrancesado, político ou descompromissado. O teatro passa a ser importante para o país do futuro, de qualquer maneira. E para mantê-lo vale bem qualquer esforço, como seduzir um coronel tonto, vender entradas na televisão, viver da TV e viver para o teatro, ou mesmo usar a fama da TV para vender melhor os espetáculos.

Se coletivamente o teatro carioca nem sempre conseguiu se manter ou desenvolver neste entendimento pluralista do ofício, ou se ainda, ao se pluralizar e se misturar à televisão, viu algumas de suas facetas mais comprometidas com ideais artísticos perderem o público ou a capacidade política intrínseca - aquela de discutir as coisas da pólis -, individualmente Fernanda Montenegro manteve em sua carreira posterior um repertório que não teve medo do trágico, do drama, da comédia rasgada ou da novela de TV. Em Fernanda, ficam evidentes os novos valores que a geração do Teatro dos Sete e particularmente a majestosa recepção de O mambembe de 1959 ajudou a fixar como parâmetro a ser seguido no teatro brasileiro: a qualidade aliada à versatilidade. A versatilidade da brilhante interpretação de Fernanda em Laudelina se consolida na atriz que brilha em qualquer situação, em qualquer veículo, em qualquer peça, filme ou programa.

A confusão que até aqui propositadamente fizemos entre atriz e personagem já foi feita pelo público e crítica da época. Barbara Heliodora, que já há alguns anos identificava o trabalho de Fernanda como o de uma lutadora por um teatro moderno e brasileiro, mistura atriz e personagem ao tecer seus elogios quanto à versatilidade e à qualidade da atriz:

O que para nós coloca Fernanda Montenegro na privilegiadíssima posição que ocupa no teatro nacional é justamente a dedicação, o entusiasmo, a disciplina, o amor com que se entrega a cada personagem, seja ele de que gênero for [...] e a Laudelina que resulta no palco é radiante de alegria e contagia a plateia com seu amor pelo teatro [...]. Seja cantando, $[\ldots]$ seja representando à portuguesa, [...] seja em dificuldades 
com as pretensões duvidosas do Coronel Pantaleão, seja enlouquecendo o seu Eduardo [...], Fernanda Montenegro é inesgotável de encanto e emoção. [...] Fernanda bem merece a canção "Elle a quelque, quelque chose, elle a quelque chose là" (HELIODORA, 1959, p. 6).

Dedicação, entusiasmo e disciplina são as atitudes esperadas das novas estrelas do teatro moderno. Uma atitude profissional que, aliada a versatilidade, poderia capacitar um artista a transformar uma peça alternativa e sem recursos em um empreendimento de qualidade profissional, ou dar qualidade artística a qualquer programa de televisão, por mais industriais que fossem suas condições de produção.

Se essa utopia não se realiza plenamente no panorama teatral e audiovisual brasileiro - por muitas razões que não cabem aqui -, no caso de Fernanda é exatamente isso que a transformou no maior nome contemporâneo de nosso teatro, cinema e TV. A capacidade de ser uma grande dama no programa mais comercial e de ser uma operária ou uma palhaça no espetáculo intelectualmente mais requintado parece existir nela a partir da abertura à complexidade do teatro moderno e contemporâneo, aliada ao mesmo compromisso de comunicabilidade imediata que Fernanda aprendeu dos nossos "artistas de bulevar".

Os jornalistas de 1959 são unânimes em dizer que a canção que fica na memória do público são as coplas de D. Laudelina, quando ela diz estar disposta a estudar muito para enfrentar a carreira de atriz, custe o que custar: "O que me alenta e consola/na carreira que me atrai/é sair da mesma escola/de onde tanto artista sai/quanta moça analfabeta ${ }^{15} / q u e$ não sabe o beabá/fez-se atriz/atriz completa/e do público ouviu já/[...] 'Elle a quelque chose là'."

Curioso pensar que o espetáculo de estreia do grupo do Teatro dos Sete, cujo projeto de conjunto incluía a modernização e o abrasileiramento da cena carioca, seja marcado e lembrado por essa canção que é uma ode afrancesada ao divismo da primeira dama. Tânia Brandão, em seu livro sobre o Teatro dos Sete, alerta para o fato de que ele foi "a casa de Fernanda Montenegro", onde seu nome se fixou como mito teatral, "com tudo que isto pudesse significar de restrição à ideia de elenco" (BRANDÃO, 2002, p. 214).

15. Nessa hora imaginamos Fernanda direcionando o "analfabeta" para as futuras colegas de Laudelina, pois ouvimos no áudio suas reações de indignação e a consequente risada da plateia. 
O Teatro dos Sete pode não ter modernizado a cena carioca, e nem abrasilerou-a como queria. Mas 0 mambembe de 1959 carimbou a carreira de uma "atriz completa" como aquela que tem "quelque chose" ou "algo mais" para ser sim, uma diva. Uma diva moderna, se é que se poderia dizer assim, pois toda vez que está em cena se subentende que ali está uma criadora - ao mesmo tempo empresária e proletária do teatro. Excelência e versatilidade que, se não deram tão certo como projeto coletivo para o teatro, resultaram no fenômeno individual de um modelo de atriz para todo o Brasil.

\section{Referências bibliográficas}

AZEVEDO, A.; PIZA, J. O mambembe. São Paulo: Martins Fontes, 2010.

BRANDÃO, C. O grande teatro tupi do Rio de Janeiro: o teleteatro e suas múltiplas faces. Rio de Janeiro: UFJF, 2005.

BRANDÃO, T. A encenação brasileira moderna. 1992. Tese (Livre Docência) - Universidade Federal do Estado do Rio de Janeiro, Rio de Janeiro.

A máquina de repetir e a fábrica de estrelas: Teatro dos Sete. Rio de Janeiro: 7Letras, 2002.

BRITTO, S. Fábrica de ilusão: cinquenta anos de teatro. Rio de Janeiro: Funarte, Salamandra, 1996.

COELHO, T. A vida de Fernanda Montenegro: depoimento a Tânia Coelho. Rio de Janeiro: Ed. Rio, 1982.

GUENZBURGER, G. Acendam as luzes, o mambembe voltou!: de Artur Azevedo ao Teatro dos Sete, redenção e idealismo na invenção póstuma da belle époque teatral. 2011. Dissertação (Mestrado em Teoria e Literatura Comparada) - Instituto de Letras, Universidade do Estado do Rio de Janeiro, Rio de Janeiro, 2011. Disponível em: <http://www.bdtd.uerj.br/tde_busca/arquivo.php?codArquivo=3251 $\geq$. Acesso em: 4 mar. 2015.

O caso Mambembe: a redenção da antirrevista no Teatro Municipal. Revista Interfaces, ano 17, n. 15, 2011. Disponível em: <http://www.cla.ufrj.br/index. php/2013-06-07-14-47-23/edicoes-publicadas/4-2012 >. Acesso em: 4 mar. 2015.

Rio, cenas decisivas: teatro entre televisão, patrocínio e política. 2015. Tese (Doutorado em Literatura Comparada) - Instituto de Letras, Universidade do Estado do Rio de Janeiro, Rio de Janeiro, 2015.

HELIODORA, B. De como se deve amar o teatro. Jornal do Brasil, Rio de Janeiro, $2^{\text {a }}$ parte, p. 6, 21 nov. 1959.

MAGNO, P. C. O mambembe no Municipal, a Ordem do Cruzeiro do Sul para o diretor Gianni Ratto. Correio da Manhã, Rio de Janeiro, v. 2, p. 3, 14 nov. 1959. 
MENCARELLI, F. A cena aberta: a absolvição de um Bilontra e o teatro de revista de Arthur Azevedo. Campinas: Editora da Unicamp, 1999.

MONTENEGRO, F. Viagem ao outro: sobre a arte do ator. Rio de Janeiro: MINC/ Funarte, 1988.

O GLOBO. Mambembe 51 anos depois: peça ganha remontagem e a crítica Barbara Heliodora relembra a montagem original, $2^{\circ}$ Caderno, 3 jun. 2010. Disponível em: <http://oglobo.globo.com/cultura/o-mambembe-51-anos-depois-peca-ganha -remontagem-a-critica-barbara-heliodora-relembra-a-2999150>. Acesso em: 5 jun. 2015.

RITO, L. Fernanda Montenegro em O exercício da paixão. Rio de Janeiro: Rocco, 1990.

SABINO, F. Mambembe. Jornal do Brasil, Rio de Janeiro, p. 7, 21 nov. 1959.

SALGADO, P. Mais coisas do Mambembe. Revista Querida, n. 137, p. 93-94, fev. 1960.

Com O mambembe pelo Teatro dos Sete. Diário de notícias, Rio de Janeiro, p. 12-13, 22 nov. 1959.

Recebido em 13/03/2015

Aprovado em 23/05/2015

Publicado em 30/06/2015 